\title{
Fungi Measurement
}

National Cancer Institute

\section{Source}

National Cancer Institute. Fungi Measurement. NCI Thesaurus. Code C154813.

The determination of the fungi present in a sample. 